\title{
Animosity towards Acid Attacks - Critical Study on Acid Victimization
}

\author{
Chandrashekar.S.V. \\ Assistant Professor, School of Criminology and \\ Criminal Justice, Rani Channamma University, \\ Belagavi, Karnataka
}

\author{
Eldo Johny \\ Teaching Assistant, School of Criminology and \\ Criminal Justice, Rani Channamma University, \\ Belagavi, Karnataka
}

\section{ABSTRACT}

Animosity to acid attacks is deliberated as foulest acts, a form of gender terrorism within the feminist read. It's a form of vicious violence outlined as acid throwing or Vitriolage. In India, there are component varied incident were reported, as most precarious victimization of individuals by deforming their body. The condition of victims of acid attacks is unit in serious frustrating their entire life. Acid victimization has deliberated globally and even several countries area unit sensitizing the problems so as to virtuously strengthen the victims. The prominence influence is to be deliberated in victim purpose of reading, firstly, whether or not specifically on raising the condition of victims by judicial reforms and with antagonistic services or arduous the criminals for victim satisfaction? Second, interference of Women victimization particularly in acid attacks, thirdly, however victims ought to live their entire life once the tragic incidents? Supported to these higher problems this paper endeavors to interpret the psychological condition of victims of acid attacks their agony and additionally the revolution within the criminal justice compelling the primary phases in determining the complete crime issues and additionally sway on society.

Keywords: Vitriolage, Women victimization, Violence against women, Criminal Justice

\section{INTRODUCTION}

There are numerous motives to light up the acid assaults primarily on women. It is deliberated as psychological oppression in the women's activist interpretation, hence it is called as a form of Gender terrorism (Robert.T.Muller, 2014) and furthermore as despises wrongdoing. Acid Throwing or Vitriolage is characterized as damaging acidic chemicals onto the body which reasons distorting skin, in Medical obsessive clarification. Deductively acid is been characterized, as a property which contains having its $\mathrm{pH}$ value underneath 7 . These destructive substances influence skin by harming whole Tissues.

There are many occasions in India of acid tossing, particularly on women. So it is well thoroughly considered that it is despise wrong doing.

\section{The Assessment of Criminal Bahaviour and Motives in Acid Attacks.}

The significant of measuring the criminal conduct of acid aggressors are little worried, , most of the crimes are with emotional complications with certain motives.. This may shift over the world, In India, the majority of victims were inclined to Love issues, Sexual abuse, Ex-accomplices revenge, Extra marital relations, Dowry, inappropriate activities, Land Issues, Property issues, and alternate reasons. Women are more inclined to the acid assaults contrasting with men, based on the review of various research study findings. 


\begin{tabular}{|l|l|l|}
\hline Features & Behaviour & Motives \\
\hline Frustrated & $\begin{array}{l}\text { Leads to } \\
\text { aggressive nature }\end{array}$ & Revenge \\
\hline Egoistic & $\begin{array}{l}\text { Nature of Putting } \\
\text { own needs } \\
\text { before others, } \\
\text { Humiliate }\end{array}$ & Build intimacy \\
\hline Seductive & $\begin{array}{l}\text { Immodest, } \\
\text { provocative } \\
\text { nature }\end{array}$ & $\begin{array}{l}\text { Sexual } \\
\text { interests }\end{array}$ \\
\hline
\end{tabular}

The Criminal Intentions gives more complexity against women victims, so it is been thought as a type of Sexual orientation Psychological oppression in the Women's activist Examinations.

\section{A. Frustrated:}

This condition would lead the individual to either Dejection or Hostility because of claim disappointments. Individual may mean to overcome by disappointment and feels to help out his own advancement. This may wind up with extreme vengeance. Relationships, Additional Conjugal Relationship, Unfaithfulness, ExAccomplice Cruelty and so forth. The vast majority of the women focused thus as the reprisal, deforming her for all time would ruin her whole life.

\section{B. Egoistic:}

This sort of bahaviour is extremely hurtful; this can be seen as "Objectification" of Women and Male-controlled Predominance. Individual when he neglects to accomplish great connection or closeness may cause genuine sort of animosity swings into to do assault by pouring corrosive. A proposal to be engaged, Love recommendations, Physically Stalking, coercion, persuasively tries to build closeness.

C. Seductive: This condition is exceptionally criticized in the societal perspectives. To increase sexual favour, sexual ill-treating. In the event that anybody flops in this, He will assault on her body, with a specific completion motive to deform her for all time.

\section{Outcome of Acid Assaults in India}

The Acid assaults are accounted for over the Indian states, it is definitely unwelcoming to check and furthermore, it is very difficult to take preventive activities. It is thought that India has seen many instances of corrosive assaults yet the conviction rate is low. The Normal age of victim is projected between 14 to 45 years; all the age women are exploited in India. The majority of the cases were accounted for with reasons of lustful wishes.

\section{Supreme Court and Central Government of India Direction to all states:}

The Supreme Court of India directs the Union Home Ministry has initiated to all states to restrict the sale of acids across the nation. It is directed to all the drug company to be following the guidelines of the government strictly in the sale of chemicals coercive in the nature, its availability. The Ministry of Home Affairs has additionally coordinated to every one of the states to force rules on the sale of acids that each medication shops ought to entirely take after the rules and keep up the data of the purchaser's registers and the explanation behind purchasing with their whole information's. It is fine up to 50,000 rupees the individuals who don't take after the strict rules. Focus government likewise has requested each state to institute their own particular law with non-safeguard capable arrangements.

\section{Compensation by the Union Government:}

The union government has ventured with the momentous starts to deal with the victim of acid assault are remunerated with no less than 3 lakh rupees. One lakh rupees should pay the victim by the within 15 days of the incident, for restorative administration. The Supreme Court of India also directed that the acid attack is Non- Bail able offence. However the Educational institutes and the other research institutes, both the academic and nonacademic, and all the health institutes which are set up the storage if acids must record the usages, to be filed and maintained. The stakeholders of these all should vigilance over the workers or the students by checking often regularly and ensure they walk without anything taken out.

\section{Laws Relating to Acid Assault in India}

TheGazette of IndiaDated April 2, 2013, went arrange through the Union Ministry of Law and Justice, authorized Criminal Law Amendment Act 2013, rolled out improvements and included to the section 
100 of Indian Penal Code under Chapter 2, of Amendment Bill,

A. Explainsseventhly, An Act of Throwing or Administering acid or an attempt to throw or administer acid which may reasonably cause the apprehension that grievous hurt will otherwise be the consequences of such act (Padala Rama Reddy, 2014).

\section{B. Section 5 of Criminal Law Amendment bill} 2013, Made amendment to the section 326A of Indian Penal code, states whoever causes permanent or partial damage or deformity to , or burns or maims or disfigures or disobeys any part or parts of the body of person or causes grievous hurt by throwing acid on or by administering acid to that person or by using any other mean with the intention of causing or with the knowledge that he is likely to cause such injury or hurt, shall be punished with imprisonment of either description for a term which shall not be less than 10 years but which may extend to imprisonment for life and with fine,. Further provided that such fine shall be just and seasonable to meet the medical expenses of the treatment of the victim's.

C. Section $326 \mathrm{~B}$, voluntarily throwing or attempting to throw acid. Whoever throws or attempts to throw acid on any person or attempts to administer acid to any person or attempts to use any other means with the intentions of causing permanent or partial damage or deformity or burns or maiming or disfigurement or disability or grievous hurt to that person, shall be punished with imprisonment of either description for term which shall not less than 5 years but may extend to 7 years shall also be liable to fine. There some explanation two explanations which further elaborated, Explanation 1, For the purpose of section 326A and this section, acid includes any substance which has acidic or corrosive character or burning nature that is capable of causing bodily injury leading to scar's or disfigurement or temporary or permanent disabilities. The Explanation 2, For the purpose of section 326A and this section permanent or partial damage or deformity shall not be required to be irreversible (Padala Rama Reddy, 2014).

\section{The considerations of acid laws and women's activist thoughts}

The acid laws in India are genuinely considered with basic perspectives. The current laws in corrosive assaults must be changed victim survivor's viewpoints are to be amplifying further genuine punishment. Numerous women's activist examinations depend on the way of punishment ought to be improved with much serious. Deforming the face is thought to be the attempt to kill, once victim loses the regular skin, makes the lasting imprint for whole life, so the considerations depend on the seriousness of the offense ought to rebuff with the level of murder attempt.

\section{Medico Legal Angles}

The acid assaults impacts are extremely egregious. Most of the guilty parties who have indulged these sorts of offenses are targets victim face and afterward different parts of the body. In such cases the medical examination while treating the victims relies on upon the force of the corrosive tossed, it just not burns but rather it influences the skin and the fat substance underneath the skin. So the measure of power is to be inspected before going to treat it. The delicate parts of the body like eyelids, lips, and if the substance goes into the nose and ears then the seriousness is profoundly perilous. That will be the changeless scar.

\section{Victim's Psychological Defies}

Acid Assaults are the most frightful act against Human body particularly to make harm on the body and in addition rationally the victims of these kinds of incidents will suffer lot through their life with so much of agony. Psychologically the assessment of acid victims especially women victims should be deliberated all over the world to make awareness and to aid victims.

\section{Post-Traumatic Stress Disorder:}

This issue can be influenced by the people the individuals who neglect to recover from the experience of horrendous circumstances,. Corrosive victims appallingly get influenced in the most the cases, because of their inclination. Acid victims terribly get affected in the most the cases, due to their proneness. Acid attacks are such offences where the victim's cognitive experience pushes them into the traumatic conditions. Victims often suffer from tragic memory. There 
are two kind of PTSD occurs, chronic a profound impact of the cognitive memory and the other one is acute, where the memories are very short. Usually women victims are more prone to this kind of disorders. The affected person may feel severe fear of culprits and the events may further lead them into be lonely or hatred- ness towards such acts.

\section{Obsessive Disorder:}

This disorder can be seen in the person mind set who suffer from repeated thought of particular traumatic event. Victims who develop such obsessive disorder may suffer themselves by cursing; also there are chances of developing the hatred ness, revenge attitudes towards culprits because of those mentally imaged memories.

\section{Frustration:}

It creates in the victims of corrosive assaults by reviling themselves since they met a sad condition.

\section{Body Dimorphic Disorder (BDD):}

Acid victims of BDD suffer about their looks, about their appearance. It's difficult to feel in the event that they get harmed to their body. Particularly in women they can't control emotions and get discouraged and stressed of their condition. Here victim may feel they can't confront society and social circumstance. That additionally may make them feel such a variety of issues. They endure in disguising, contrasting themselves with others, consistent checking in mirror, makes them distress.

5. Misandry:

This regularly found in women, it hatred towards men and young men. This is due to objectification of women for sexual lust. The victims who develop misandry feel much furious and dread.

\section{Methodology}

\section{The Objectives of the study}

1. To analyse and Explicate the problems of Acid Victimization.

2. To study the consequences of Acid attacks and Victim Proneness and to review it statistically.

3. To Deliberate Acid assailant's motives.

Methods: The motivation behind this investigation is to examine the animosity towards acid victimization along with full filling the objectives stated above. This analysis receives the Explorative Descriptive methods. This data gathered through the Secondary source from the organization Acid Survivours Foundation India.

The following numbers represents the acid attack incidents from 2011 to 2015 in India.

\begin{tabular}{|l|c|c|c|c|c|c|}
\hline State & $\mathbf{2 0 1 1}$ & $\mathbf{2 0 1 2}$ & $\mathbf{2 0 1 3}$ & $\mathbf{2 0 1 4}$ & $\mathbf{2 0 1 5}$ & TOTAL \\
\hline Andrapradesh & 8 & 6 & 4 & 6 & 14 & 38 \\
\hline $\begin{array}{l}\text { Arunachal } \\
\text { Pradesh }\end{array}$ & 0 & 0 & 0 & 0 & 0 & 00 \\
\hline Assam & 0 & 1 & 13 & 0 & 3 & 17 \\
\hline Bihar & 3 & 10 & 1 & 4 & 19 & 37 \\
\hline Chattisgarah & 0 & 0 & 0 & 1 & 0 & 01 \\
\hline Goa & 0 & 1 & 0 & 0 & 0 & 01 \\
\hline Gujrat & 2 & 4 & 5 & 6 & 4 & 21 \\
\hline Haryana & 8 & 6 & 6 & 13 & 12 & 45 \\
\hline Himachal & 0 & 0 & 1 & 1 & 1 & 03 \\
\hline Jammu \& & 2 & 3 & 2 & 2 & 2 & 11 \\
\hline Kashmir & 0 & 1 & 0 & 3 & 0 & 04 \\
\hline Jharkhand & 3 & 2 & 4 & 3 & 2 & 14 \\
\hline Karnataka & 1 & 2 & 0 & 4 & 10 & 17 \\
\hline Kerala & 5 & 6 & 11 & 20 & 19 & 61 \\
\hline Madhya Pradesh & 6 & 3 & 9 & 5 & 8 & 31 \\
\hline Maharastra & 0 & 0 & 0 & 0 & 1 & 01 \\
\hline Manipur & 0 & 1 & 0 & 0 & 0 & 01 \\
\hline Meghalaya & & & & & & \\
\hline
\end{tabular}




\begin{tabular}{|l|c|c|c|c|c|c|}
\hline Mizoram & 0 & 0 & 0 & 0 & 0 & 00 \\
\hline Nagaland & 0 & 0 & 1 & 0 & 0 & 01 \\
\hline Odisha & 1 & 2 & 3 & 10 & 8 & 24 \\
\hline Punjab & 9 & 4 & 5 & 17 & 7 & 42 \\
\hline Rajasthan & 0 & 6 & 0 & 6 & 1 & 13 \\
\hline Sikkim & 0 & 0 & 0 & 2 & 0 & 02 \\
\hline Tamil Nadu & 0 & 1 & 6 & 13 & 10 & 30 \\
\hline Telangana & 0 & 0 & 0 & 1 & 1 & 02 \\
\hline Tripura & 0 & 1 & 0 & 4 & 4 & 09 \\
\hline Uttar Pradesh & 14 & 11 & 18 & 43 & 61 & 147 \\
\hline Uttarkhand & 2 & 3 & 0 & 0 & 0 & 45 \\
\hline West Bengal & 13 & 22 & 8 & 41 & 41 & 125 \\
\hline A\& N Islands & 0 & 0 & 0 & 0 & 0 & 00 \\
\hline Chandigarh & 1 & 0 & 1 & 0 & 0 & 02 \\
\hline D \& N Haveli & 0 & 0 & 0 & 0 & 0 & 00 \\
\hline Daman \& Diu & 0 & 0 & 0 & 0 & 0 & 00 \\
\hline Delhi Ut & 28 & 9 & 18 & 20 & 21 & 96 \\
\hline Lakshadeep & 0 & 0 & 0 & 0 & 0 & 00 \\
\hline Puducherry & 0 & 1 & 0 & 0 & 0 & 01 \\
\hline Total & $\mathbf{1 0 6}$ & $\mathbf{1 0 6}$ & $\mathbf{1 1 6}$ & $\mathbf{2 2 5}$ & $\mathbf{2 4 9}$ & $\mathbf{8 0 2}$ \\
\hline
\end{tabular}

Source: Acid Survivors Foundation India (Statistics).

The above numerical understandings demonstrate the event of occurrences during that time 2011 to 2015. This interpretation includes all the states of India including Union Territories of India. The extent of increase in the offense incidents proves to us how the pattern creating in the countries. In 2011 the offenses were accounted for just 106 all through India, which compasses to 249 when 2015, which can be dissected twofold. Thoroughly as per the figures, 802 cases were accounted for from 2011 to 2015. The offense extent varies each year, yet the 2011 and in the time of 2012 no distinction by any stretch of the imagination. The expanding patterns propose that the rate of wrongdoing episodes are a little worry, in the time of 2015 it as expanded twofold contrasting with 2011 information. Among every one of the states, Uttar Pradesh stands most surprising crime event in all out five years it is 147 incidents. Besides the condition of West Bengal has announced 125 violations by and large over the most recent five years, taking after that Delhi as a Union territory stood third most noteworthy acid assault crimes. Strangely among all the Union territories, Delhi alone has high crime rate. While Arunachal Pradesh, Mizoram, Andaman Nicobar, Daman and Diu, D\& N Haveli, Lakshadweep are never seen any acid assault incidents.

\section{Results and Discussions}

The following table indicates Rate of increased acid attack at various States of India

\begin{tabular}{|c|c|c|}
\hline Year & $\begin{array}{c}\text { Number } \\
\text { of attack }\end{array}$ & $\begin{array}{c}\text { Rate Of increase } \\
\text { in acid Attack }\end{array}$ \\
\hline $\mathbf{2 0 1 1}$ & 77 & - \\
\hline $\mathbf{2 0 1 2}$ & 96 & 24.68 \\
\hline $\mathbf{2 0 1 3}$ & 97 & 1.05 \\
\hline $\mathbf{2 0 1 4}$ & 205 & 111.35 \\
\hline $\mathbf{2 0 1 5}$ & 228 & 11.22 \\
\hline
\end{tabular}

The above numbers demonstrate the rate of expanded corrosive assault at different states in India, the extent in the year 2012, announced cases are 96, from 2011 to 2012 inside one year the patterns are transformed it expanded at the rate of 24.68. In the year 2013, the occurrences were 97, the following year to it 2014 has 205 cases enlisted. The rate of an episode has expanded around 111.35 twofold to the genuine numbers. The expanding pattern proceeded in the year 2015 again with the rate of 11.22 . This picture indicates us somewhere close to the year 2012 to 2013 crime rate as less rate of expanded with just $1.05 \%$. Incidentally the latest amendment for Criminal Procedure Code (Amendment) act 2013, made severe 
laws due to the disruption of Nirbhaya incident, also direction of Supreme Court of India made rigid decisions for free treatment; compensations, regulating and control of sale of acids strengthen the laws. During 2013 to 2014 within one year of span the acid incidents were $111.35 \%$ high in the nation. There should have been less, because the aftermath Nirbhaya case it was furious to the law and order condition also to the policy makers. Later 2014 the increasing rate has been lowered to just $11.22 \%$. This may be due to the sensational alertness among judiciary, police and citizens due to the Nirbhaya incident. The following table indicates Rate of increase in acid attack in $\mathrm{U} / \mathrm{T}$

The following table indicates Rate of increase in acid attack in $\mathrm{U} / \mathrm{T}$

\begin{tabular}{|l|l|l|}
\hline Year & $\begin{array}{l}\text { Number } \\
\text { of attack }\end{array}$ & $\begin{array}{l}\text { Rate Of increase in } \\
\text { acid Attack }\end{array}$ \\
\hline $\mathbf{2 0 1 1}$ & 29 & - \\
\hline $\mathbf{2 0 1 2}$ & 10 & -65.52 \\
\hline $\mathbf{2 0 1 3}$ & 19 & 90 \\
\hline $\mathbf{2 0 1 4}$ & 20 & 5.27 \\
\hline $\mathbf{2 0 1 5}$ & 21 & 5 \\
\hline
\end{tabular}

The Union Territories saw low quantities of the corrosive assault occurrences contrasting with the states. It is in the Time of 2013 the crime rate expanded by $90 \%$. In the year 2015 , it is been just $5 \%$. Obviously, the wrongdoing rate in the Union domains is less. Most elevated among the union territories is Delhi. By and large in India still, the numbers recommends that there ought to be some component to control such intolerable corrosive assaults which are extremely severe in nature.

\section{Findings and Suggestions:}

The findings of the study,

1. The size of the Corrosive assaults occurrences is in unsafe condition to direct the wrongdoings. Still, it is expanding subsequently we require a decent approach with inflexible punishment with no hesitancy.

2. The crime incidents in Eastern states are less in numbers, might be the geological and social immovability of the land as affected, Arunachal Pradesh and Mizoram never saw any such corrosive assaults.
3. Andaman Nicobar, Daman and Diu, D\& N Haveli, Lakshadweep have never seen any corrosive assault incidents.

4. Uttar Pradesh, West Bengal, and Delhi are positioned most elevated wrongdoing occurrences. Maybe the controls on the sale of chemicals are to be taken honest, Particularly in Delhi as a capital city; more consideration ought to be paid. West Bengal is second most elevated, due to the border security and migration problems, with Neighbour country Bangladesh the identity problem among the people is worried, even in Worldwide Situation Bangladesh has the high risk in acid assaults, based on the many research reports.

\section{CONCLUSION}

The Vitriolage are intense offenses, the reported incidents and the size of the offense demonstrate that the crime occurrences are expanding each year; still, there are some sure potential outcomes of Dark figures of crime. The greater part of the rural areas are going unreported because of different reasons, maybe the crime incidents are less. The strict control on the drug dealers and the chemical suppliers might help to combat these issues. And the strategy of highest punishments would impact population to not do such offenses. There is need of good Victim survey's at the governmental level as well.

\section{REFERENCES}

1) Taylor, L. M. (2000). Saving Face: Acid Attack Laws After the UN Convention on the Elimination of All Forms of Discrimination Against Women.Ga. J. Int'l \& Comp. L., 29, 395.

2) Anwary, A. (2003). Acid violence and medical care in Bangladesh: Women's activism as carework. Gender \& Society, 17(2), 305-313.

3) AmbikaPandit (2017) Rules for Government jobs to acid attack survivors to be notified soon.

4) Law Commission of India Report - 226 ( 2009) Proposal for inclusion of acid attacks as specific offences in Indian penal code and a Law for compensation for victim of crime.

5) Acid Survivours Foundation India.

6) Padala Rama redid(2014) Indian Penal Code, $1860.16^{\text {th }}$ edition, Asia Law House, Hyderabad. 